\title{
Spectacular efficacy of neoadjuvant chemotherapy in a patient with cervical cancer of IB2 grade according to FIGO 2009
}

Spektakularna skuteczność chemioterapii neoadiuwantowej u pacjentki z rozpoznaniem raka szyjki macicy w stopniu IB2 według FIGO 2009 r.

\section{Kamila Kaźmierczak', Błażej Nowakowski, ${ }^{1,2}$, Joanna Kufel-Grabowska1,3,4, Witold Cholewiński ${ }^{4,5}$}

1 Surgical, Oncological and Endoscopic Gynaecology Department, Greater Poland Cancer Centre, Poznan, Poland

2 Department of Oncologic Pathology and Prophylaxis, Poznan University of Medical Sciences, Poznan, Poland

Department of Clinical Oncology, Greater Poland Cancer Centre, Poznan, Poland

4 Chair and Department of Electroradiology, The Faculty of Health Sciences, Poznan University of Medical Sciences, Poznan, Poland

5 Nuclear Medicine Unit, Greater Poland Cancer Centre, Poznan, Poland

Correspondence: Kamila Kaźmierczak Department of Electroradiology, Poznań University of Medical Sciences, Greater Poland Cancer Centre 61-688 Poznań, Poland, Garbary 15 e-mail: kamilka35@icloud.com

Received:

27.04.2020

Accepted:

30.06.2020

DOI: 10.24292/01.OR.220300620.6 Copyright $\odot$ Medical Education. All rights reserved.

\section{ABSTRACT}

The presented case report is an example of a spectacular effect of induction systemic treatment in a patient with locally advanced cervical cancer of IB2 grade according to FIGO 2009 (International Federation of Gynecologist and Obstetrician). The effect of induction chemotherapy (three series in paclitaxel/24 $\mathrm{h}+$ cisplatin regimen at an interval of three weeks) was the total metabolic response of the primary tumor and nodal lesions found in FDG-PET/CT (18F-fluorodeoxyglucose - positron emission tomography combined with computed tomography) as well as an image of total regression of the tumor in the obtained postoperative histopathological examination.

Key words: cervical cancer, neoadjuvant chemotherapy, positron emission tomography

\section{STRESZCZENIE}

Przedstawiony opis przypadku jest przykładem spektakularnego efektu zastosowania chemioterapii neoadiuwantowej (NACT, neoadjuvant chemotherapy) u pacjentki z miejscowo zaawansowanym rakiem szyjki macicy w stopniu IB2 według FIGO 2009 r. (International Federation of Gynecologist and Obstetrician). Efektem zastosowanej chemioterapii indukcyjnej (trzech serii w schemacie paklitaksel/24 h + cisplatyna w odstępie 3-tygodniowym) była całkowita odpowiedź metaboliczna guza pierwotnego i zmian węzłowych stwierdzona w badaniu FDG-PET/CT (18F-fluorodeoksyglukoza pozytonowa tomografia emisyjna połączona z tomografią komputerową), a także obraz całkowitej odpowiedzi patologicznej w otrzymanym pooperacyjnym badaniu histopatologicznym.

Słowa kluczowe: rak szyjki macicy, chemioterapia neoadiuwantowa, pozytonowa tomografia emisyjna 


\section{WSTĘP}

Rak szyjki macicy pod względem częstości zachorowań jest czwartym po raku piersi nowotworem złośliwym u kobiet na świecie. W 2012 r. zarejestrowano 528000 nowych przypadków zachorowań i 265672 zgony z powodu tego nowotworu na świecie [1].

Chociaż na przestrzeni ostatnich kilkudziesięciu lat obserwuje się tendencję do zmniejszenia się zachorowalności na raka szyjki macicy w krajach wysokorozwiniętych - taki trend ma miejsce także w naszym kraju - to nadal śmiertelność jest wysoka.

Według najnowszych danych Krajowego Rejestru Nowotworów w 2017 r. zachorowały w Polsce 2502 kobiety, ale w tym samym czasie zmarło 1609, czyli ponad połowa [2]. Wysoki wskaźnik umieralności na raka szyjki macicy wynoszący 7,8/100 000 kobiet w Polsce lokuje nas na jednym z ostatnich miejsc wśród państw Europy.

Średnia europejska 5-letnich przeżyć względnych dla inwazyjnego raka szyjki macicy wynosi $63,5 \%$. Polska z wynikiem $49 \%$ lokuje się na jednym z ostatnich miejsc w Europie. Taki wynik jest spowodowany niską skutecznością badań przesiewowych, dużym procentem pacjentek $w$ wysokim stadium zaawansowania w momencie rozpoznania i/lub niską jakością leczenia.

W ostatnich latach zaobserwowano, że zachorowalność zwiększa się w grupie kobiet młodszych (35-44 lata), nadal jednak najwięcej, bo 30\% zachorowań dotyczy kobiet między 45. a 49. r.z. [3].

Z uwagi na stosunkowo młody wiek chorych na raka szyjki macicy ewentualne ryzyko ich zgonu jest przyczyną utraty wielu lat życia (YLL, years of life lost), a w przypadku pacjentek wyleczonych - wielu potencjalnych lat życia po terapii, co z kolei powinno skupiać naszą uwagę na jakości życia po leczeniu [4].

Sposób terapii raka szyjki macicy zależy od stadium zaawansowania w momencie rozpoznania choroby. Do pierwotnego leczenia chirurgicznego kwalifikowane są chore we wczesnych stopniach zaawansowania klinicznego według FIGO, tj. IA-IIA. Ponad 70\% chorych zgłasza się jednak do leczenia w stopniach wyższych od IIB do IV według klasyfikacji FIGO 2009. Dlatego niecałe $30 \%$ chorych na raka szyjki macicy w Polsce może być pierwotnie leczonych chirurgicznie [5].

W wybranych przypadkach przed leczeniem operacyjnym można zastosować chemioterapię neoadiuwantową. Dotyczy to zwłasz-

\section{INTRODUCTION}

Cervical cancer is the fourth most common malignant cancer in women in the world after breast cancer. In 2012, 528 thousand new cases and 265672 thousand deaths from this cancer were registered worldwide [1].

Although over the last several decades there have been tendencies to reduce the incidence of cervical cancer in highly developed countries - such a trend is also observed in our country, the mortality rate is still high.

According to the latest data from the National Cancer Register, 2502 women fell ill in Poland in 2017, but 1609, i.e. more than half of them died at the same time [2]. The high cervical cancer mortality rate of 7.8/100,000 thousand women in Poland places us in one of the last places among European countries.

The European average of 5-year relative survival rates for invasive cervical cancer is $63.5 \%$. With a score of $49 \%$, Poland occupies one of the last places in Europe. This result is due to low screening efficacy, high percentage of patients at a high stage at the time of diagnosis and/or poor quality of treatment.

In recent years, it has been observed that the incidence of the disease is increasing in the group of younger women (35-44 years), however, still the highest number of cases, i.e. $30 \%$ of the cases concern women between 45-49 years of age [3].

Due to the relatively young age of patients with cervical cancer, the possible risk of their death is the cause of many years of life lost (YLL), and in the case of cured patients, many potential years of life after treatment, which in turn should focus our attention on the quality of life after treatment [4].

The treatment of cervical cancer depends on the stage of progress at the time of diagnosis. Patients in early stages of clinical advancement according to $\mathrm{FIGO}$, i.e. IA-IIA, are qualified for primary surgical treatment. However, more than $70 \%$ of patients are enrolled for treatment in stages II B to IV according to FIGO 2009. Therefore, only less than $30 \%$ of patients with cervical cancer in Poland may be initially treated surgically [5].

In selected cases, neoadjuvant chemotherapy may be applied before the surgical treatment. This is especially true in patients with locally advanced cervical cancer and/or metastatic lymph nodes. 
cza pacjentek z miejscowo zaawansowanym rakiem szyjki macicy i/lub obecnością przerzutowych węzłów chłonnych. Zastosowanie NACT przed leczeniem operacyjnym ma na celu nie tylko zmniejszenie objętości guza, ale przede wszystkim ograniczenie przerzutów zwłaszcza w obrębie węzłów chłonnych. Według dostępnego piśmiennictwa zastosowanie NACT przed leczeniem operacyjnym zwiększa możliwość zaniechania uzupełniającej radioterapii i/lub poprawia jej wyniki. Dobra tolerancja leczenia chemicznego, brak progresji choroby oraz wysoki odsetek remisji patologicznych zachęcają do zastosowania systemowego leczenia indukcyjnego. Niemniej jednak największą korzyść stanowi wpływ NACT na zmniejszenie ryzyka zgonu i wydłużenie całkowitego przeżycia [3].

\section{OPIS PRZYPADKU}

64-letnia pacjentka z gruczołowym rakiem szyjki macicy rozpoznanym na podstawie badania histopatologicznego wycinków z części pochwowej została skierowana do poradni ginekologii onkologicznej w celu kwalifikacji do dalszego leczenia. Na podstawie przeprowadzonego badania przedmiotowego stwierdzono guz szyjki macicy obejmujący tylną wargę wielkości powyżej $4 \mathrm{~cm}$, bez naciekania przymacicz i sklepień pochwy. W celu zaplanowania terapii wykonano u pacjentki badanie FDG-PET/CT, które poza guzowatym naciekiem części pochwowej szyjki macicy o wymiarach $36 \times 37 \times 46 \mathrm{~mm}$ wykazało przerzutowe węzły chłonne biodrowe obustronnie; po stronie prawej dwa o średnicy 12 i 9 mm, po stronie lewej jeden o średnicy 15 mm (ryc. 1). Według klasyfikacji FIGO z 2009 r. ustalono rozpoznanie raka szyjki macicy w stopniu IB2.

W przeszłości rozpoznano u pacjentki niekrwawiące tętniaki lustrzane tętnic szyjnych wewnętrznych po obustronnej dwukrotnej implantacji stentów, z tego powodu chora pobierała kwas acetylosalicylowy w dawce $75 \mathrm{mg} / 24 \mathrm{~h}$. Po analizie sytuacji klinicznej ze względu na wielkość guza powyżej $4 \mathrm{~cm}$ oraz stwierdzenie obecności przerzutowych węzłów chłonnych w badaniu FDG-PET/CT podjęto decyzję o rozpoczęciu leczenia od chemioterapii neoadiuwantowej w schemacie paklitaksel/24 h + cisplatyna. Podano trzy serie chemioterapii w odstępach 3-tygodniowych bez powikłań. 2 tygodnie po trzecim podaniu chemioterapii wykonano kontrolne badanie FDG-PET/CT, które wykazało całkowitą odpowiedź metaboliczną na zastosowane leczenie guza pierwotnego oraz zmian węzłowych (ryc. 2).
The use of NACT prior to surgical treatment is not only to reduce the volume of the tumour, but also to reduce metastases, especially within the lymph nodes. According to the available literature, the use of NACT prior to surgical treatment increases the possibility of discontinuing adjuvant radiotherapy and/or improves its results. Good tolerance of cytostatic treatment, lack of disease progression and high percentage of pathological remissions encourage the use of systemic induction therapy. However, the greatest benefit is the impact of NACT on reducing the risk of death and prolonging overall survival [3].

\section{CASE STUDY}

Patient, aged 64, diagnosed on the basis of a histopathological examination, with vaginal specimens of cervical glandular cancer was referred to the Oncology Outpatient Clinic for qualification for further treatment. On the basis of the physical examination, a cervical tumor was found, including a posterior lip over $4 \mathrm{~cm}$ in size, without infiltration on the parametrium and vaginal vaults. In order to plan the treatment, the patient underwent an FDG-PET/CT examination, which, apart from a $36 \times 37 \times 46 \mathrm{~mm}$ vaginal infiltration of the cervical part, showed metastatic hip lymph nodes on both sides; on the right side two with diameter 12 and $9 \mathrm{~mm}$, on the left side one with diameter $15 \mathrm{~mm}$ (fig. 1). According to the 2009 FIGO classification, the patient was diagnosed with IB2 grade cervical cancer.

In the past, the patient was diagnosed with non-bleeding mirror aneurysms of internal carotid arteries after bilateral double stent implantation; for this reason, the patient received $75 \mathrm{mg}$ of acetylsalicylic acid daily. After the analysis of the clinical situation due to the tumor size above $4 \mathrm{~cm}$ and the presence of metastatic lymph nodes in the FDG-PET/CT study, it was decided to start the treatment with neoadjuvant chemotherapy in the regimen of paclitaxel $(24 \mathrm{~h})+$ cisplatin. Three series of chemotherapy at three-week intervals without complications were administered. Two weeks after the third administration of chemotherapy, a control FDG-PET/CT examination was performed, which showed a total metabolic response to the applied treatment of the primary tumor and nodal lesions (fig. 2). 
RYCINA 1. Guzowaty naciek szyjki macicy z wysokim gromadzeniem FDG oraz patologiczne węzły chłonne biodrowe. FIGURE 1. Nodular cervical infiltration with high FDG accumulation and pathological hip lymph nodes.

A
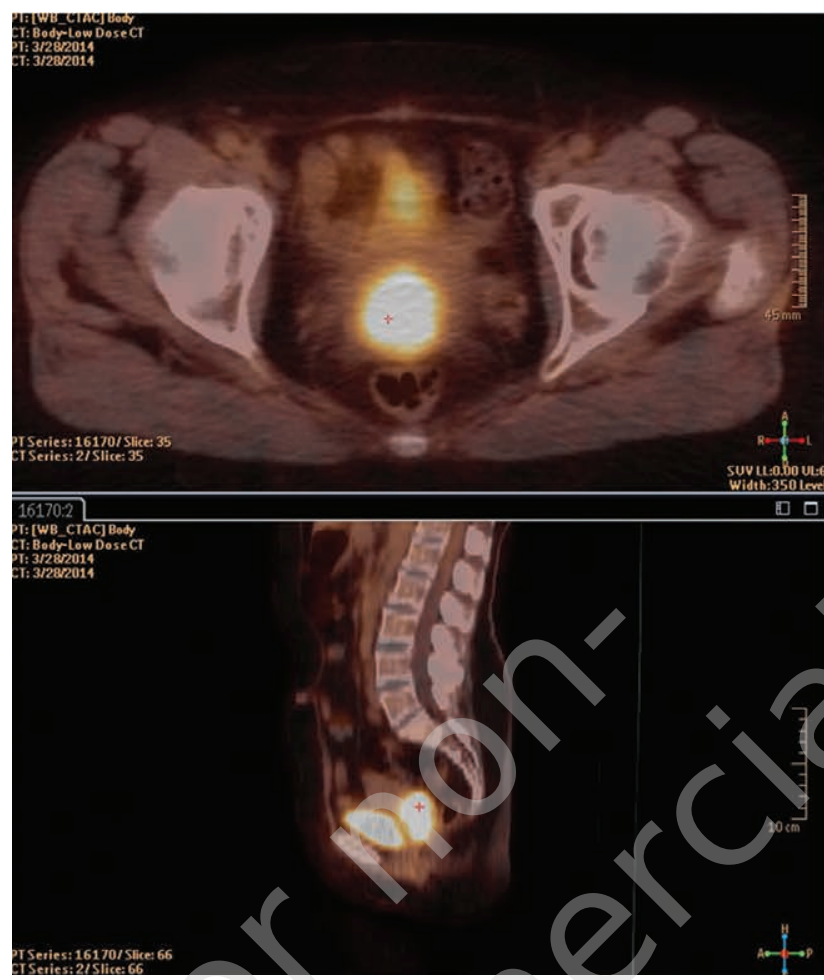

$\rightarrow$
B

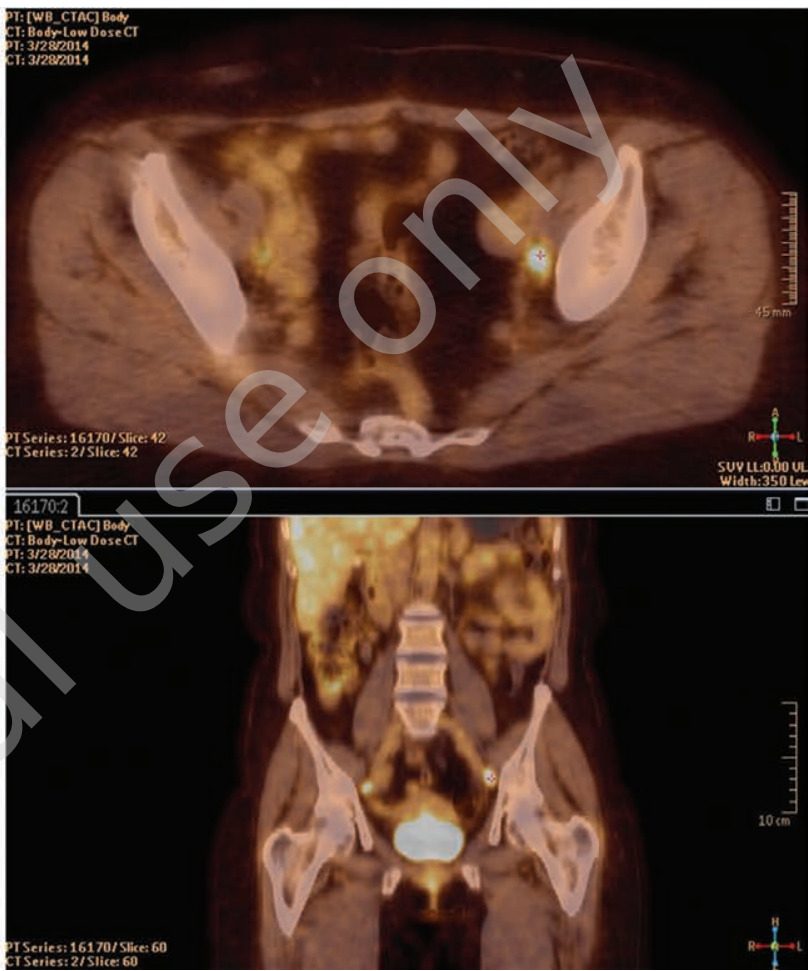

RYCINA 2. Całkowita odpowiedź metaboliczna na zastosowane leczenie. A. Badanie przed leczeniem. B. Badanie po chemioterapii. FIGURE 2. Total metabolic response to the treatment applied. A. Pre-treatment test. B. Post-treatment test.

A

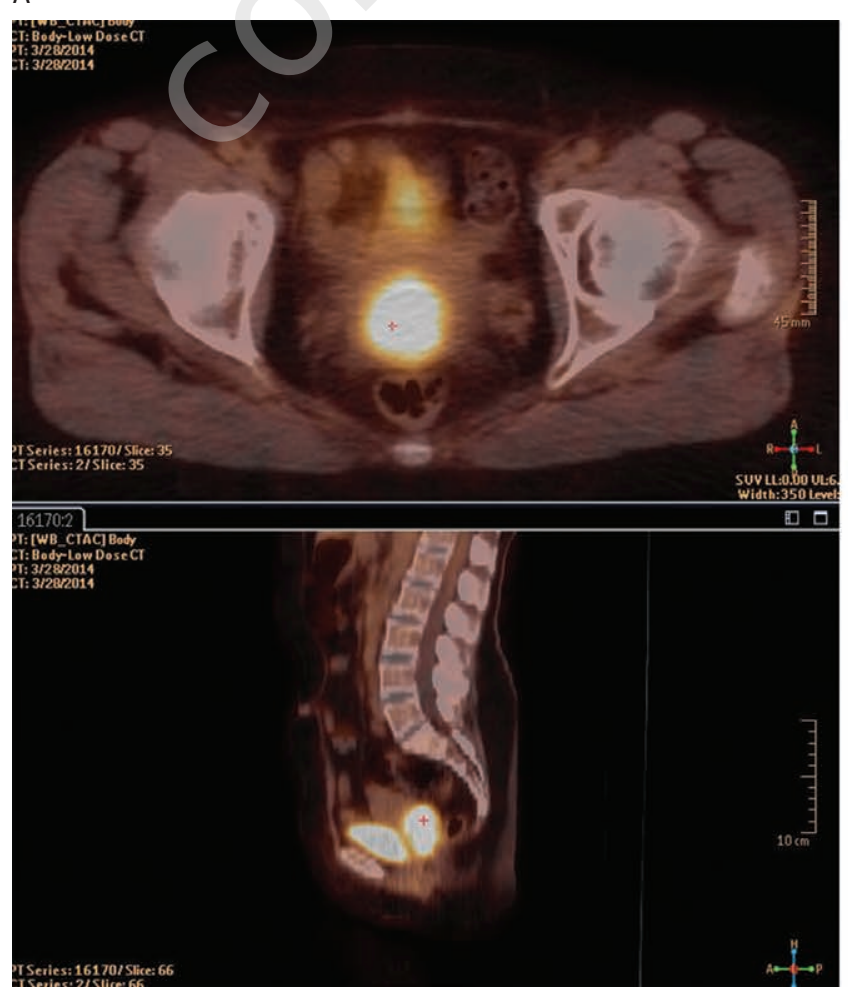

B

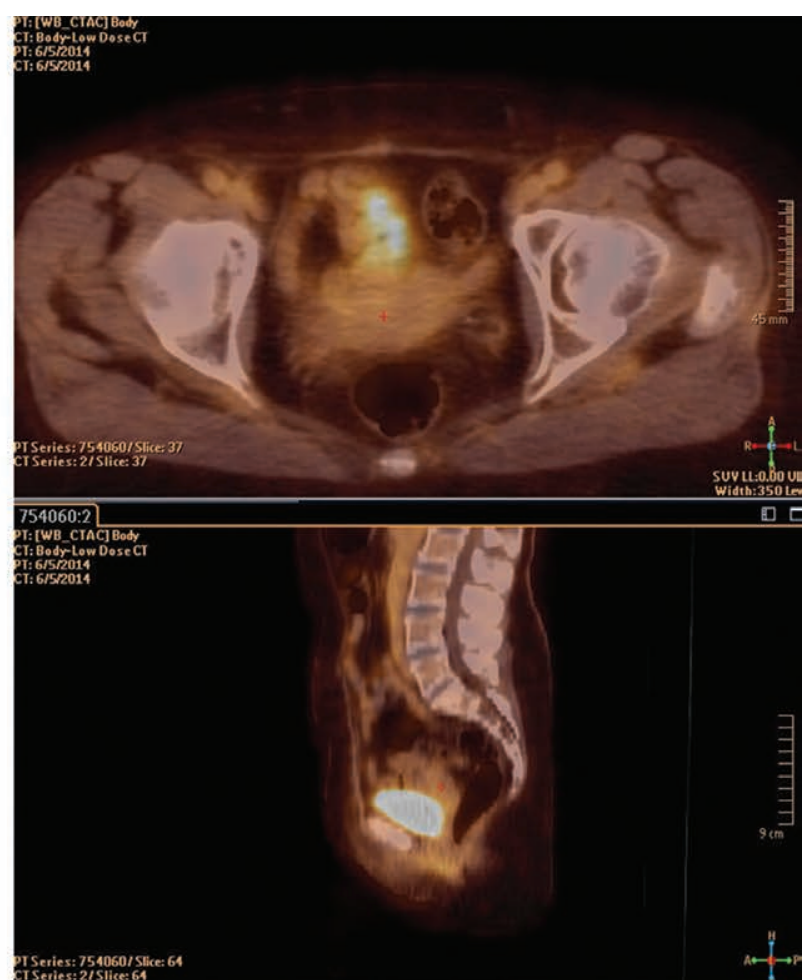


Po trzech seriach chemioterapii neoadiuwantowej wykonano u pacjentki radykalną histerektomię z uwzględnieniem morfogenezy tkanek TMMR (total mesometrial resection) według Höeckel wraz z terapeutyczną limfadenektomią (tLND, therapeutic lymph node dissection). TMMR to rodzaj zmodyfikowanej radykalnej histerektomii, której celem jest wycięcie en bloc jednostki dystalnej pochodzącej z przewodu Müllera. Niezbędnym jej elementem jest także tLND miednicza do poziomu rozwidlenia aorty. Zakres tej operacji jest jednoznacznie precyzyjnie określony, a jednocześnie nie nakazuje ślepego szerokiego usuwania tkanek nienarażonych na wystąpienie wznowy, będąc tym samym rodzajem operacji oszczędzającej typu nerve sparing. Poza zakresem operacji innym istotnym jej elementem jest zasada minimalnej traumatyzacji tkanek, co zmniejsza ilość powstałej blizny - miejsca sprzyjającego wznowie. Operację przeprowadzono zgodnie ze standardem, a chemioterapię adiuwantową rozpoczęto w 7. dobie po operacji, zastosowano identyczny schemat lekowy.

W pooperacyjnym wyniku badania histopatologicznego stwierdzono całkowitą regresję guza (całkowita odpowiedź patologiczna). W żadnym z 39 usuniętych węzłów chłonnych nie znaleziono przerzutu. Leczenie systemowe kontynuowano do piątej serii. Miesiąc po leczeniu operacyjnym u pacjentki zdiagnozowano obecność przetoki moczowodowo-pochwowej. Wykonano urografię, a pacjentkę zakwalifikowano do leczenia operacyjnego po wygojeniu rany pooperacyjnej. 3 miesiące od pierwotnej operacji raka szyjki macicy pacjentkę zoperowano z dobrym skutkiem, przeszczepiając prawy moczowód do pęcherza moczowego. Pacjentka została zakwalifikowana do regularnych wizyt kontrolnych w poradni ginekologii onkologicznej.

W trakcie 5-letniej obserwacji nie stwierdzono u pacjentki cech wznowy raka szyjki macicy. Poza objawami pęcherza nadreaktywnego skutecznie leczonego zachowawczo pacjentka nie zgłaszała innych dolegliwości związanych z przebytą terapią. Pozostawała w kontroli poradni ginekologii onkologicznej przez 5 lat, następnie została skierowana do dalszych kontroli w rejonowej poradni ginekologicznej.

\section{DYSKUSJA}

Przedstawiony przypadek pacjentki z rozpoznaniem raka szyjki macicy w stopniu IB2 według FIGO 2009 r. jest bardzo interesujący, ponieważ pomimo pierwotnego lokoregionalnego zaawansowania choroby udało się uzyskać wyleczenie. Badanie obrazowe FDG-PET/CT poza potwierdzeniem wielkości guza pierwotnego szyjki macicy dostarczyło dodatkowej istotnej wiedzy klinicznej o istnieniu przerzutowych węzłów chłonnych, co było kluczowe
After three series of neoadjuvant chemotherapy a radical hysterectomy with TMMR (total mesometrial resection) and tLND (therapeutic lymph node dissection) according to Höeckel was performed. TMMR is a type of modified radical hysterectomy, the aim of which is to cut out en bloc the distal unit coming from Müller's duct. Therapeutic pelvic lymphadenectomy up to the level of the aortic bifurcation is also an essential element. The scope of this operation is unambiguously precise and at the same time it does not require blind wide removal of tissues not exposed to the recurrence, thus being a kind of nerve sparing procedure. Outside the scope of the operation, another important element is the principle of minimal tissue traumatization, which reduces the amount of scarring - a place conducive to relapse. The operation was performed according to the standard and adjuvant chemotherapy was started on day $7^{\text {th }}$ after the operation, the same drug regimen was used.

The postoperative histopathological examination revealed complete regression of the tumour (total pathological response). No metastasis was found in any of 39 removed lymph nodes. Systemic treatment was continued until fifth series. One month after the surgical treatment the patient was diagnosed with the presence of urethral vaginal fistula. Urography was performed and the patient was qualified for surgical treatment after healing the postoperative wound. Three months after the initial operation of cervical cancer, the patient was successfully operated, transplanting the right ureter into the bladder. The patient was qualified for regular check-ups to the Oncology Outpatient Clinic.

During the 5-year follow-up, the patient did not show signs of recurrent cervical cancer. Apart from the symptoms of the hyperreactive bladder successfully treated conservatively, the patient did not report other complaints related to the treatment. She remained under the control of the Oncology Outpatient Clinic for 5 years, then she was referred for further control at the Regional Gynaecology Outpatient Clinic.

\section{DISCUSSION}

The presented case of a patient with a diagnosis of cervical cancer grade IB2 according to FIGO 2009 is very interesting, because the recovery was achieved despite the primary locoregional severity of the disease. In addition to confirming the size of the primary cervical tumor, FDG-PET/CT imaging provided further important clinical knowledge about the existence of metastatic lymph nodes, which was crucial in deciding to start treatment with neoadjuvant chemotherapy. 
w podjęciu decyzji o rozpoczęciu leczenia od chemioterapii neoadiuwantowej.

Jednym ze wskazań do zastosowania przedoperacyjnej chemioterapii indukcyjnej poza zmniejszeniem objętości guza w celu uzyskania wtórnej jego operacyjności jest ograniczenie przerzutowania, zwłaszcza do węzłów chłonnych. U opisywanej pacjentki guz szyjki przekraczał $4 \mathrm{~cm}$ i prezentował wysoką aktywność metaboliczną (SUV ${ }_{\text {max }}$ do 9,0), natomiast podejrzane węzły chłonne biodrowe obustronnie: dwa po stronie prawej i jeden po lewej poza znamienną wielkością (9 mm, $12 \mathrm{~mm}$ i $15 \mathrm{~mm}$ ) charakteryzowały się istotnie podwyższonym gromadzeniem FDG wskazującym na istnienie choroby przerzutowej (SUV ${ }_{\text {max }}$ węzłów odpowiednio 1,$8 ; 2,9 ; 4,0$ ).

Istotnymi czynnikami prognostycznymi dla stopnia zaawansowania raka szyjki macicy FIGO IA2-IIA 2009 są: obecność lub brak przerzutów w węzłach chłonnych, średnica guza pierwotnego, głębokość naciekania podścieliska, naciek na przymacicza, zajęcie naczyniowej lub limfatycznej przestrzeni naczyniowej (LVSI, lymphovascular space invasion), zróżnicowanie histologiczne raka, obecność lub brak marginesu prawidłowej tkanki w preparacie pooperacyjnym. Znaczenie ma także typ histologiczny nowotworu. Do najważniejszych negatywnych czynników prognostycznych należą: obecność przerzutów w węzłach chłonnych, średnica guza przekraczająca $4 \mathrm{~cm}$ oraz zajęcie LVSI.

Niekorzystnym prognostycznie typem histologicznym raka szyjki macicy jest jego postać gruczołowa (adenocarcinoma), która w porównaniu z typem płaskonabłonkowym cechuje się większym ryzykiem przerzutów do węzłów chłonnych - ok. 20\% (typ płaskonabłonkowy 15\%), większym ryzykiem nawrotów - 21\% (typ płaskonabłonkowy 15\%) oraz przeżyciem 5-letnim na poziomie 76\% (typ płaskonabłonkowy 84\%) dla chorych leczonych operacyjnie [3].

Według piśmiennictwa największą korzyść z zastosowania neoadiuwantowej chemioterapii odnoszą chore z miejscowo zaawansowanym rakiem szyjki macicy w stopniu IB2. Wyniki dwóch dużych metaanaliz wykazały, że w porównaniu z podejściem klasycznym NACT zastosowana zarówno przed leczeniem operacyjnym, jak i przed napromienianiem ma statystycznie istotny, pozytywny wpływ na zmniejszenie ryzyka zgonu oraz wydłużenie przeżycia całkowitego. Pozytywny wpływ NACT był bardziej wyrażony, jeśli była stosowana przed zabiegiem chirurgicznym niż przed radioterapią [6-8]
One of the indications for the use of preoperative induction chemotherapy, in addition to reducing the volume of the tumor for secondary surgery, is to reduce metastasis, especially to lymph nodes. In the patient described, the cervical tumor exceeded $4 \mathrm{~cm}$ and showed high metabolic activity (SUV $\mathrm{max}_{\text {ma }}$ up to 9.0), whereas suspected hip lymph nodes on both sides: two on the right and one on the left, except for a significant size ( $9 \mathrm{~mm}, 12 \mathrm{~mm}$ and $15 \mathrm{~mm}$ ) were characterized by considerably increased FDG accumulation indicating metastatic disease (node SUV $_{\max } 1.8 ; 2.9 ; 4.0$ respectively).

Important prognostic factors for the severity of cervical cancer FIGO IA2-IIA 2009 are: presence or absence of metastases in the lymph nodes, diameter of the primary tumor, depth of perivascular parenchyma infiltration, lymphovascular space invasion (LVSI), histological differentiation of the cancer, presence or absence of margin of normal tissue in the postoperative preparation. The histological type of the cancer is also important. The most important negative prognostic factors include the presence of lymph node metastases, tumor diameter exceeding $4 \mathrm{~cm}$ and LVSI involvement.

The unfavorable histological type of cervical cancer is adenocarcinoma, which compared to the squamous type is characterized by a higher risk of lymph node metastases - about $20 \%$ (squamous type 15\%), higher risk of relapse - $21 \%$ (squamous type $15 \%$ ) and 5 -year survival of $76 \%$ (squamous type $84 \%$ ) for patients undergoing surgery [3].

According to the literature, the greatest benefit from neoadjuvant chemotherapy is provided for patients with IB2 grade locally advanced cervical cancer. The results of two large meta-analyses showed that, compared to the classical approach, NACT used both before surgery and irradiation has a statistically significant, positive effect on the reduction of the risk of death and prolonged total survival. The positive effect of NACT was more pronounced when used before surgery than before radiotherapy [6-8].

The meta-analysis of 5 clinical trials involving a total of $441 \mathrm{pa}-$ tients with cervical cancer FIGO IB2-III included the comparison of two types of treatment: neoadjuvant chemotherapy and surgery with radical radiotherapy. In the arm with NACT + radical surgical treatment, the risk of death was significantly reduced compared to radiotherapy, i.e. by $35.0 \%(H R=0.65 ; p=0.0004)$ and a $14 \%$ increase in 5 -year survival $(64.0 \%$ vs. $50.0 \%)$ was observed [7]. 
W metaanalizie pięciu badań klinicznych obejmujących łącznie 441 pacjentek z rakiem szyjki macicy FIGO IB2-III porównano dwa rodzaje leczenia: neoadiuwantową chemioterapię oraz operację z radykalną radioterapią. W ramieniu z NACT + radykalne leczenie chirurgiczne stwierdzono znaczące zmniejszenie ryzyka zgonu w porównaniu z radioterapią o $35 \%(H R=0,65 ; p=0,0004)$ oraz 14-procentowy wzrost przeżyć 5-letnich (64\% vs 50\%) [7].

Natomiast w metaanalizie porównującej NACT z następowym radykalnym leczeniem chirurgicznym z samodzielną radykalną chirurgią stwierdzono, że u pacjentek leczonych NACT oraz radykalną chirurgią odnotowuje się lepszą lokalną kontrolę $(O R=0,67 ; 95 \%$ $\mathrm{Cl} 0,45-0,99 ; p=0,04)$ oraz znaczne zmniejszenie niekorzystnych zmian patologicznych $(\mathrm{OR}=0,54 ; \mathrm{p}<0,0001$ dla statusu węztów chłonnych; $\mathrm{OR}=0,58 ; \mathrm{p}=0,002$ dla nacieku przymacicz) [8].

W kolejnym badaniu wieloośrodkowym, którego wstępne wyniki zostały opublikowane w maju 2019 r. i dotyczyły badania klinicznego EORTC 55994 porównującego wyniki chemioterapii neoadiuwantowej z następową operacją z chemioradioterapią raka szyjki macicy w stadium IB2-IIB, pierwszorzędowym punktem końcowym było 5-letnie przeżycie (OS). Mediana czasu obserwacji wyniosła 8,2 roku i była podobna w obu ramionach. 5-letni OS wyniósł 72\% w ramieniu 1 i $76 \%$ w ramieniu 2 (nieistotne statystycznie, różnica $=4 \%$ ). Reasumując, nie wykazano różnicy w 5-letnim przeżyciu między chemioterapią neoadiuwantową a następnie operacją ze standardową równoczesną chemoradioterapią. Dotychczas nie opublikowano jeszcze wyników dotyczących częstości nawrotów choroby w obydwu grupach [9].

Jednak nie wszystkie doniesienia są tak budujące. W zakończonym badaniu klinicznym III fazy z randomizacją porównującym NACT z następową chirurgią i pooperacyjną radioterapią z samodzielną radiochemioterapią wykazano przewagę drugiej metody. Analizowano przypadki pacjentek z miejscowo zaawansowanym płaskonabłonkowym rakiem szyjki macicy w stadium IB2, IIA i IIB (316 w grupie NACT + chirurgia i 317 w grupie radiochemioterapii). Porównano 5-letnie czasy wolne od choroby - gorsze wyniki uzyskano dla grupy z NACT + chirurgia (69,3\% vs $74,7 \%)$, jednak bez wpływu na całkowite przeżycia 5-letnie (75,4\% vs $74,7 \%)$. Należy zaznaczyć, że badanie to nie dotyczyło pacjentek z rozpoznaniem histologicznym gruczołowego raka szyjki macicy [10].

\section{PODSUMOWANIE}

Opisywany przypadek kliniczny pacjentki jest pozytywnym przykładem, że pomimo pierwotnego zaawansowania lokore-
On the other hand, another meta-analysis, comparing NACT with the subsequent radical surgical treatment with independent radical surgery, revealed that the patients treated with NACT and radical surgery had better local control $(\mathrm{OR}=0.67 ; 95 \% \mathrm{Cl}$ $0.45-0.99 ; p=0.04$ ) and a significant reduction of adverse pathological changes $(O R=0.54 ; p<0.0001$ for lymph node status; $O R$ $=0.58 ; p=0.002$ for perimetrium infiltration) [8].

In a subsequent multicenter study, the initial results of which were published in May 2019, the clinical trial EORTC 55994 compared the results of neoadjuvant chemotherapy with a subsequent surgery with cervical cancer chemotherapy in stage IB2-IIB. The primary end-point was a 5-year survival (OS). The median observation time was 8.2 years and was similar in both arms. The 5 -year OS was $72 \%$ in arm 1 and $76 \%$ in arm 2 (statistically insignificant, difference $=4.0 \%$ ). To sum up, there was no difference in a 5 -year survival between neoadjuvant chemotherapy and subsequent surgery with standard concomitant chemoradiotherapy. At present, the results concerning the frequency of relapse in both groups have not been published yet [9].

But not all reports are so encouraging. The only current phase III clinical trial with randomization comparing NACT with subsequent surgery and postoperative radiotherapy with independent radiochemiotherapy showed the advantage of the second method. Cases of patients with local advanced cervical squamous cell carcinoma in IB2, IIA and IIB stages have been analysed (316 in the NACT + surgery group and 317 in the radiotherapy group). 5-year disease-free times were compared - worse results were obtained for the group with NACT + surgery $(69.3 \%$ vs. $74.7 \%)$, but without affecting the total 5 -year survival $(75.4 \%$ vs. $74.7 \%)$. It should be noted that this study did not apply to patients with histological diagnosis of cervical adenocarcinoma [10].

\section{SUMMARY}

The described clinical case of the patient is a positive example that despite the primary locoregional severity of cervical cancer and unfavorable prognostic factors: histological type (glandular form), tumor size above $4 \mathrm{~cm}$ and presence of metastatic lymph nodes, combination of chemotherapy and surgery enabled to cure the patient. The 5-year follow-up period showed no relapse. During the follow-up visits, the patient did not report any significant side effects related to the systemic or surgical treatment. 
gionalnego raka szyjki oraz niekorzystnych czynników prognostycznych: typ histologiczny (postać gruczołowa), wielkość guza powyżej $4 \mathrm{~cm}$ oraz obecność przerzutowych węzłów chłonnych, połączenie chemioterapii i operacji umożliwiło wyleczenie pacjentki. 5-letni okres obserwacji nie wykazał nawrotu choroby. W czasie wizyt kontrolnych pacjentka nie zgłaszała istotnych związanych z przeprowadzonym leczeniem działań niepożądanych, zarówno systemowym, jak i chirurgicznym.

\section{Piśmiennictwo/References}

1. International Agency for Research on Cancer - IARC, Gobocan 2012. Estimated cancer incidence, mortality and prevalence worldwide 2015. http:// globocan.iarc.fr.

2. Wojciechowska U, Didkowska J. Zachorowania i zgony na nowotwory złośliwe w Polsce, Krajowy Rejestr Nowotworów, Centrum Onkologii - Instytut im. Marii Skłodowskiej-Curie. http://onkologia.org.pl/raporty (Access: 3.04.2020).

3. Markowska J, Mądry J. Zarys ginekologii onkologicznej. Vol. 1. Termedia, Poznań 2018: 622-30, 797-8, 736-8.

4. Nowakowski A, Kotarski J. Rak szyjki macicy w Polsce i na świecie w świetle danych o zapadalności i umieralności. Przegl Epidemiol. 2011; 65: 75-9.

5. Bidziński M, Dańska-Bidzińska A. Chirurgiczne leczenie raka szyjki macicy. Ginekol Pol. 2007; 78: 723-6.

6. Benedetti-Panici P, Greggi S, Colombo A et al. Neoadjuvant chemotherapy and radical surgery versus exclusive radiotherapy in locally advanced squamous cell cervical cancer: results from the Italian multicenter randomized study. J Clin Oncol. 2002; 20(1): 179-88.

7. Neoadjuvant Chemotherapy for Locally Advanced Cervical Cancer Meta-analysis Collaboration. Neoadjuvant chemotherapy for locally advanced cervical cancer: a systematic review and meta-analysis of individual patient data from 21 randomized trials. Eur J Cancer. 2003; 39(17): $2470-86$.

8. Rydzewska L, Tierney J, Vale CL et al. Neoadjuvant chemotherapy plus surgery versus for cervical cancer. Cochrane Database Syst Rev. 2012; 12(12): CD007406.

9. Kenter G, Greggi S, Vergote I et al. Results from neoadjuvant chemotherapy followed by surgery compared to chemoradiation for stage Ib2-II b cervical cancer, EORTC 55994. J Clin Oncol. 2019; 37(15 suppl): 5503.

10. Gupta S, Maheshwari A, Parab P et al. Neoadjuvant Chemotherapy Followed by Radical Surgery Versus Concomitant Chemotherapy and Radiotherapy in Patients With Stage IB2, IIA, or IIB Squamous Cervical Cancer: A Randomized Controlled Trial. J Clin Oncol. 2018; 36(16): 1548-55.

Authors' contributions: Kamila Kaźmierczak: 60\%; Błażej Nowakowski: 10\%; Joanna Kufel-Grabowska: 10\%; Witold Cholewiński: 20\%.

Conflict of interests: None.

Financial support: None. Ethics:

The authors had full access to the data and take full responsibility for its integrity. All authors have read and agreed with the content of the manuscript as written. The paper complies with the Helsinki Declaration, EU Directives and harmonized requirements for biomedical journals. 